\title{
PENGARUH EKSTRAK AIR BAWANG PUTIH (Allium sativum) TERHADAP MORTALITAS LARVA Crocidolomia binotalis PADA TANAMAN KUBIS
}

\author{
Debby D. Moniharapon dan Maria Nindatu \\ Dosen Jurusan Biologi FMIPA Universitas Pattimura Ambon \\ E-mail: mey_nindatu@yahoo.com
}

\begin{abstract}
Background: Garcil (Allium sativum) is an important commodity and has high economic value in Indonesia.Studies have been using water extracts of garcil as larval mortality Crocidolomia binotalis in august -september 2014. This study aimed to determine the effect of water extract of Garlic (Allium sativum) on mortality of larvae on cabbage plants Crocidolomia binotalis.

Methods: This study was an experimental study, using a rando mized block design (RBD), using the control group, and treatment concentraction of water extracts of garlic (Allium sativum). Concentration ranging from $2 \%, 4 \%, 6 \%, 8 \%$ with observation for 24 hours. Data effect of aqueous extract of garlic is effective against larval mortality Crocidolomia binotalis analyzed by real difference test (LSD) and the determination of the value of LC50, using SPSS.

Result: The results showed the water extract of garlic is effective for larval mortality Crocidolomia binotalis is the concentration of $6 \%$ and of probit analysis LC50 values of $4,632 \%$.

Conclusion: Concentration of $4,632 \%$ aqueous extract of garlic (Allium sativum) can kill larvae Crocidolomia binotalis after administration of the extract and observation for 24 hours.
\end{abstract}

Keyword: Garcil, Water Extract, Mortality, Larve.

\begin{abstract}
Abstrak
Latar Belakang: Bawang putih (Allium sativum) merupakan komoditi penting dan mempunyai nilai ekonomis tinggi di Indonesia. Telah dilakukan penelitian yang menggunakan ekstrak air bawang putih sebagai mortalitas larva (Crocidolomia binotalis) pada bulan Agustus - September 2014. Penelitian ini bertujuan untuk mengetahui pengaruh ekstrak air bawang putih (Allium sativum) terhadap mortalitas larva Crocidolomia binotalis pada tanaman kubis.

Metode: Penelitian ini merupakan penelitian eksperimental, menggunakan rancangan acak lengkap (RAL), menggunakan kelompok kontrol dan perlakuan konsentrasi ekstrak air bawang putih (Allium sativum). konsentrasi dimulai dari $2 \%, 4 \%, 6 \%, 8 \%$ dengan pengamatan selama 24 jam. Data pengaruh ekstrak air bawang putih (Allium sativum) yang efektif terhadap mortalitas larva Crocidolomia binotalis dianalisis dengan uji beda nyata (BNT) dan penentuan nilai LC50, menggunakan program SPSS.

Hasil: Hasil penelitian menunjukan ekstrak air bawang putih (Allium sativum) efektif untuk mortalitas larva Crocidolomia binotalis adalah konsentrasi $6 \%$ dan dari analisis probit nilai LC50 sebesar 4,632\% Kesimpulan: konsentrasi $4,632 \%$ ekstrak air bawang putih mampu mematikan $50 \%$ larva Crocidolomia binotalis setelah pemberian ekstrak dan pengamatan selama 24 jam.
\end{abstract}

Kata Kunci: Bawang Putih, Ekstrak Air, Mortalitas, Larva. 


\section{PENDAHULUAN}

Peningkatan produksi sayuran di Indonesia sangat diperlukan untuk memenuhi kebutuhan dalam negeri guna mengimbangi laju pertambahan penduduk yang semakin meningkat pula. Selain itu, penting juga adanya upaya peningkatan produksi sayuran untuk keperluan ekspor dan substitusi. Hal ini sesuai dengan tujuan utama pembangunan nasional di sektor pertanian yaitu menaikkan produksi pertanian.

Berbagai jenis hasil pertanian, sayuran merupakan bahan pangan penting bagi penduduk Indonesia yang diperlukan setiap hari. Sayuran yang ditanam, kubis (Brassica oleracea var. capitata $L$.) banyak diusahakan dan dikonsumsi karena sayuran tersebut dikenal sebagai sumber vitamin B, mineral, karbohidrat, protein dan lemak yang amat berguna bagi kesehatan. Seperti beberapa jenis sayuran lainnya, kubis memiliki sifat mudah rusak, berpola produksi musiman dan tidak tahan disimpan lama. Sifat mudah rusak ini dapat disebabkan oleh daun yang lunak dan kandungan air cukup tinggi, sehingga mudah ditembus oleh alat-alat pertanian dan hama atau penyakit tanaman.

Ulat crop (Crocidolomia binotalis) merupakan hama yang penting pada tanaman kubis. Munculnya hama ini pada pertanaman kubis merupakan ancaman yang serius bagi petani. Pada tahun 1998 Balai Proteksi Tanaman Pangan \& Hortikultura $\mathrm{V}$ melaporkan (C. binotalis) merupakan hama yang menempati urutan pertama penyebab kerusakan tanaman kubis di Jawa Tengah. Serangan $C$. binotalis pada tanaman kubis sampai sekarang belum dapat diatasi secara memuaskan, meskipun pengendalian kimia telah dilakukan secara intensif. Pengendalian kimiawi yang dilakukan secara intensif atau secara berulang dapat berdampak bagi lingkungan dan atas dasar itulah Perlindungan Tanaman merupakan cara untuk mencegah adanya hama dan penyakit yang dapat merusak tanaman sehingga menurunkan hasil dari tanaman tersebut (Triharso,1996).

Banyak cara yang dilakukan dalam mengendalikan hama di lapangan,cara yang paling sering dilakukan adalah dengan menggunakan insektisida. Dalam perkembangannya cara ini banyak kekurangan antara lain terjadi residu, timbulnya resistensi serangga dan pencemaran lingkungan (Anonim 2013). Penggunaan ekstrak tumbuhan sebagai salah satu sumber insektisida didasarkan atas pemikiran bahwa mekanisme pertahanan dari tumbuhan akibat interaksinya dengan serangga pemakan tumbuhan, salah satunya dihasilkan senyawa metabolik sekunder oleh tumbuhan yang bersifat sebagai penolak, penghambat perkembangan dan sebagai bahan kimia yang mematikan serangga dengan cepat (Priyono,1999). Dari hasil penelitian Adriana (1999) mengemukakan bahwa, ekstrak bawang putih memiliki daya kerja sebagai insektisida terhadap Sitophilus zeamays pada konsentrasi $7 \%$ mampu menurunkan populasi serangga turunan pertama menjadi nol. Selanjutnya Hasil penelitian Amiranti (2005) mengemukakan Ekstrak bawang putih berpengaruh terhadap tingkat kematian larva Culex pipiens pada konsentrasi 4 ppm dalam pelarut aquades dengan tingkat kematian larva mencapai $98,8 \%$. Zat Alicin yang terkandung dalam bawang putih yang menyerang sel-sel saraf pada larva sehingga menyebabkan kematian pada larva. Tujuan dari penelitian ini adalah : Untuk mengetahui pengaruh ekstrak air bawang putih (Allium sativum) terhadap mortalitas larva Crocidolomia binotalis dan dosis efektif air bawang putih (Allium sativum) efektif terhadap mortalitas Crocidolomia binotalis.

\section{MATERI DAN METODE PENELITIAN Waktu dan Tempat Penelitian}

Penelitian ini dilakukan di Laboratorium Taxonomy, Fakultas Matematika dan IImu Pengetahuan Alam Universitas Pattimura Ambon. Penelitian ini dilaksanakan pada bulan Agustus-September 2014.

\section{Alat dan Bahan}

Bahan yang digunakan dalam penelitian ini adalah: Bawang putih , larva Crocidolomia binotalis, Aquades. Sedangkan alat-alat yang digunakan adalah: Kamera digital, wadah, blender, botol spray, gelas ukur, pinset, tisuu rol, dan alat tulis menulis. 


\section{Rancangan Penelitian}

Rancangan yang dipakai dalam penelitian ini adalah rancangan acak lengkap (RAL), dengan 5 perlakuan dan 4 kali pengulangan sehingga terdapat 20 satuan percobaan. Ke -5 perlakuan tersebut dapat dirinci sebagai berikut:

$\mathrm{K} 1=$ Kontrol

$\mathrm{K} 2=2 \mathrm{~g}$ ekstrak + aqudes $100 \mathrm{ml}$

$\mathrm{K} 3=4 \mathrm{~g}$ ekstrak + aqudes $100 \mathrm{ml}$

$\mathrm{K} 4=6 \mathrm{~g}$ ekstrak + aqudes $100 \mathrm{ml}$

$\mathrm{K} 5=8 \mathrm{~g}$ ekstrak + aqudes $100 \mathrm{ml}$

Dari perlakuan yang dirinci diatas (K1) sebagai kontrol (K2) $2 \%$, (K3) $4 \%$, (K4) $6 \%$, (K5) $8 \%$.

\section{Prosedur Kerja \\ Penyiapan Serangga Uji dan Pengujian}

Larva Crocidolomia binotalis sebagai bahan uji diambil dari lahan pertanian didaerah suli bawah, kemudian diletakan dalam wadah yang telah disediakan, kemudian dibawah ke Laboratorium taxonomy untuk dipersiapkan untuk hewan uji penelitian.

\section{Pembuatan Ekstrak}

Bawang putih yang akan digunakan dikupas terlebih dahulu, ditimbang, sesuai dengan konsentrasi. Untuk konsentrasi pertama $2 g$ bawang putih ekstrak + aqudes $100 \mathrm{ml}$, konsentrasi $4 \mathrm{~g}$ ekstrak + aqudes $100 \mathrm{ml}$, konsentarsi $6 \mathrm{~g}$ bawang ekstrak + aqudes $100 \mathrm{ml}$, konsentrasi $8 \mathrm{~g}$ bawang ekstrak + aqudes $100 \mathrm{ml}$ kemudian diendapkan selama 24 jam agar zat-zat aktif yang terkandung dalam bawang putih larut dalam pelarut.

a. Selanjutnya larutan ekstrak air bawang putih disaring dan diendapkan secara perlahan-lahan sehingga mendapatkan ekstrak air bawang putih.

b. Menempatkan larutan ekstrak air bawang putih dalam botol yang telah disediakan.

\section{Perlakuan Dengan Ekstrak Bawang Putih}

a. Memindakan larva kedalam wadah yang telah disiapkan untuk setiap perlakuannya. b. Setiap wadah diisi 10 larva

c. Semprotkan ekstrak bawang putih pada daun kubis yang akan dijadikan sebagai pakan larva (empat kali semprotan untuk setiap daun).

d. Masing-masing perlakuan diulang sebanyak 4 kali ulangan.

Setelah perlakuan dilakukan untuk mendapatkan hasil yang maksimal dilakukan pengamatan selama 24 jam

\section{Pengamatan Mortalitas}

Parameter yang diamati adalah prosentase mortalitas larva Crocidolomia binotalis dilihat dari tidak adanya pergerakan dari larva dan perubahan warna pada tubuh larva dari menjadi coklat kehitaman,tubuh membentuk setegah lingkaran dan tidak bergerak sama sekali bila disentuh.

\section{Analisa Data}

Pengaruh ekstrak air bawang putih (Allium sativum) terhadap mortalitas Crocidolomia binotalis ditetapkan berdasarkan nilai LC50. Konsentrasi ekstrak air bawang putih yang dapat mematikan $50 \%$ larva Crocidolomia binotalis, penentuan ini dilakukan dengan menggunakan analisa probit. Sedangkan untuk membedakan antara perlakuan dari beberapa konsentrasi terhadap mortalitas Larva Crocidolomia binotalis menggunakan Analisis Varian satu arah (ANOVA) pada tingkat kepercayaan $95 \% \quad(\mu=0,05)$, selanjutnya nilai LC50 dihitung dengan menggunakan metode analisa Logit origin 8.

\section{HASIL DAN PEMBAHASAN}

Hasil

\section{Data Mortalitas Larva Crocidolomia binotalis Selama 24 jam Dengan Ekstrak Air Bawang Putih (Allium sativum)}

Hasil penelitian pengaruh ekstrak air bawang putih (Alliumsativum) terhadap mortalitas larva Crocidolomia binotalis dapat dilihat pada tabel 1. 
Tabel 1. Rata-Rata Mortalitas Larva Crocidolomia binotalis Selama 24 Jam Dengan Ekstrak Air Bawang Putih (Allium sativum).

\begin{tabular}{cccc}
\hline Perlakuan & Konsentrasi (\%) & Jumlah Rata-rata & Rata-rata \% (X士SD) \\
\hline Kontrol & - & 0 & 0 \\
1 & 2 & 3 & $30 \pm 14,1$ \\
2 & 4 & 5,5 & $55 \pm 19,14$ \\
3 & 6 & 8,75 & $87 \pm 15$ \\
4 & 8 & 9,25 & $100 \pm 0$ \\
\hline
\end{tabular}

$\begin{array}{lll}\text { Berdasarkan tabel terlihat bahwa } & \text { mencapai } 100 \% . & \begin{array}{c}\text { Berdasarkan } \\ \text { ekstrak pawang putih pada }\end{array} \text { perhitungan rata-rata mortalitas terlihat } \\ \text { konsentrasiterendah } 2 \% \text { menyebabkan } & \text { bahwa semakin tinggi konsentrasi ekstrak air } \\ \text { rata-rata mortalitas larva Crocidolomia } & \text { bawang putih yang digunakan maka } \\ \text { binotalis sebesar } 30 \% \text {, sedangkan pada } & \text { semakin meningkat. Presentase mortalitas } \\ \text { konsentrasi } 4 \% \text { rata-rata mortalitas naik } & \text { larva Crocidolomia binotalis. Berdasarakan } \\ \text { menjadi } 55 \% \text {. Untuk kosentrasi } 6 \% \text { rata-rata } & \text { data tersebut maka dibuat grafik ekstrak air } \\ \text { mortalitas sebesar } 87,5 \% \text { dan pada } & \text { bawang putih terhadap presentase larva } \\ \text { konsentrasi } 8 \% \text { rata-rata mortalitas } & \text { Crocidolomia binotalis (gambar } 1 \text { ). }\end{array}$

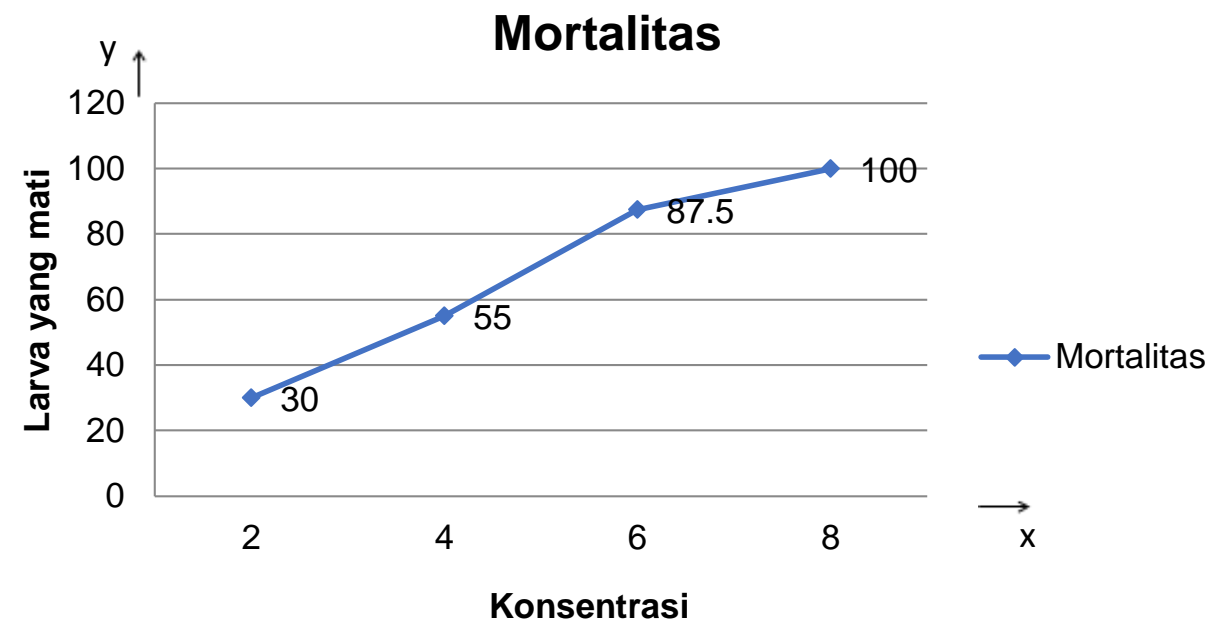

\section{Gambar 1. Grafik Pengaruh Ekstrak Air Bawang Putih (Allium sativum) Terhadap Persentase Larva (Crocidolomia binotalis).}

Berdasarkan Gambar 1 terlihat bahwa konsentrasi ekstrak air bawang putih mempengaruhi tingkat mortalitas larva Crocidolomia binotalis. Semakin tinggi konsentrasi yang digunakan maka tingkat mortalitas larva Crocidolomia binotalis akan semakin besar. Hal ini disebabkan karena, semakin banyak zat aktif yang terkandung di dalam hasil ekstrak air bawang putih tersebut, sehingga tingkat mortalitas akan meningkat. Mortalitas larva Crocidolomia binotalis setelah 24 jam diduga karena pengaruh zat aktif yang terdapat di dalam ekstrak air bawang putihyaitu Allicin.

\section{Analisis Sidik Ragam (ANOVA) \\ Hasil ANOVA mortalitas larva} Crocidolomia binotalis pada tabel 2 . 
Tabel 2. Hasil Analisis Sidik Ragam (ANOVA) Ekstrak Bawang Putih (Allium sativum) Terhadap Mortalitas Larva Crocodidolomia Binotalis Selama 24 Jam Pengamatan.

\begin{tabular}{lccccc}
\hline & DF & Sum of Squares & Mean Squares & F Value & Prob>F \\
\hline Regression & 4 & 76325 & 19081,25 & 88,37632 & $5,55475 \mathrm{E}-8$ \\
Residual & 11 & 2375 & 215,90909 & & \\
Uncorreted & 15 & 78700 & & & \\
CorrTotalected & 14 & 13360 & & & \\
\hline
\end{tabular}

Ket: terdapat perbedaan yang nyata $(\mathrm{P}<0,05)$

Berdasarkan hasil analisis sidik ragam pada Tabel 3, terlihat bahwa nilaiFhitung > Ftabel $(P<\alpha=0,05)$. Hal ini membuktikan bahwa terdapat pengaruh secara signifikan ekstrak bawang putih terhadap mortalitas larva Crocidolomia binotalis.

Hasil uji lanjut menggunakan Tukey test yang terterah pada Lampiran 3untuk masing-masing perlakuan konsentrasi ekstrak air bawang putih (Allium sativum) terhadap mortalitas larva Crocidolomia binotalis selama 24 jam pengamatan menyimpulkan bahwa dengan sigma 1 menunjukan bahwa kedua konsentrasi berbeda nyata, Sigma 0 menunjukan bahwa kedua konsentrasi tidak berbeda nyata didaptakan bahwa konsentrasi $2 \%$ berbeda nyatadengan control, konsentrasi $4 \%$ berbeda nyata dengan control, konsentrasi $4 \%$ tidak berbeda nyata dengan konsentrasi $2 \%$, konsentrasi $6 \%$ berbeda nyata dengan control, konsentrasi $6 \%$ berbeda nyata dengan konsentrasi $2 \%$, konsentrasi $6 \%$ berbeda nyata dengan konsentrasi $4 \%$, konsentrasi $8 \%$ berbeda nyata dengan control, konsentrasi $8 \%$ berbeda nyata dengan konsentrasi $2 \%$, konsentrasi $8 \%$ berbeda nyata dengan konsentrasi $4 \%$, konsentrasi $8 \%$ tidak berbeda nyata dengan konsentrasi $6 \%$, konsentrasi $8 \%$ berbeda nyata dengan konsentrasi $2 \%$,konsentrasi $8 \%$ berbeda nyata dengan konsentrasi $4 \%$, konsentrasi $8 \%$ tidak berbeda nyata dengan konsentrasi $6 \%$.

\section{Penentuan LC50 ekstrak air bawang putih (Allium sativum) terhadap mortalitas larva Crocidolomia binotalis.}

Penentuan LC50 dimaksudkan untuk melihat konsentrasi yang tepat yang membunuh 50\% larva. Untuk menentukan nilai LC50 disajikan pada tabel 3.

Tabel 3. Nilai LC50 Ekstrak Air Bawang Putih (Allium sativum) Terhadap Mortalitas Larva Crocidolomia Binotalis Setelah Pengamatan 24 Jam.

\begin{tabular}{ccc}
\hline Mortalitas (\%) & Konsentrasi (\%) & Tingkat kepercayaan (\%) \\
\hline 50 & 4,632 & 95 \\
\hline
\end{tabular}

Berdasarkan tabel 2, menunjukan nilai LC50 sebesar 4,632\%, yang berarti pada konsentrasi $4,632 \%$ ekstrak air bawang putih mampu mematikan 50\% larva Crocidolomia binotalis yang digunakan setelah pemberian ekstrak selama24 jam pada tingkat kepercayaan $95 \%$.

\section{PEMBAHASAN}

Berdasarkan hasil penelitian terlihat bahwa semua perlakuan ekstrak air bawang putih (Allium sativum) yang diberikan berpengaruh nyata terhadap mortalitas larva Crocidolomia binotalis. Berdasarkan hasil pengujian ini dapat dikemukakan bahwa ekstrak air bawang putih (Allium sativum) yang diujikan mempunyai pengaruh yang efektif terhadap larva Crocidolomia binotalis dan persentase mortalitas pada konsentrasi $8 \%$ sebesar $100 \%$. Sesuai dengan pendapat Munford dan Northon (1984) dikutip oleh Herminanto et al (2004) bahwa suatu insektisida dikatakan efektif apabila mampu mematikan minimal $80 \%$ serangga uji.

Pemberian ekstrak air bawang putih (Allium sativum) berpengaruh terhadap angka mortalitas larva Crocidolomia binotalis, halini ditunjukan dengan nilai $F$ Hitung > F Tabel. Selain itu hasil BNT menunjukan bahwa konsentrasi $8 \%$ memberikan efek yang sama terhadap 
mortalitas larva Crocidolomia binotalis bila dibandingkan dengan konsentarsi $2 \%$ $4 \%$ dan $6 \%$. Hal ini menunjukan bahwa pada konsentrasi yang lebih tinggi terjadi peningkatan angka kematian larva Crocidolomia binotalis. Mortalitas Crocidolomia binotalis diduga karena bawang putih (Allium sativum) yang mengandung Allicin. Allicin adalah komponen aktif utama bawang putih yang kerjanya menghambat pembentukan protein di dinding sel, sehingga akan cacat pada dinding sel dan system metabolismenya terganggu.

Dari hasil penelitian Adriana (1999) mengemukakan bahwa, ekstrak bawang putih memiliki daya kerja sebagai insektisida terhadap Sitophilus zeamays pada konsentrasi $7 \%$ mampu menurunkan populasi serangga turunan pertama menjadi nol. Mortalitas tersebut disebabkan adanya zat Allicin yang terkandung dalam bawang putih menyerang sel-sel saraf pada larva sehingga menyebabkan kematian.

Berdasarkan gambar 5 grafik pengaruh ekstrak air bawang putih (Allium sativum) terhadap mortalitas Crocidolomia binotalis, menunjukan bahwa semakin tinggi konsentrasi ekstrak air bawang putih diberikan, maka semakin tinggi persentase kematian larva Crocidolomia binotalis. Hal ini diduga karena adanya pengaruh kandungan Allicin yang terdapat pada ekstrak air bawang putih yang masuk kedalam tubuh larva Crocidolomia binotalis akan menggangu system saraf larva Crocidolomia binotalis sehingga larva tersebut mengalami kematian. Menurut Priyono (1999) Berdasarkan tingkat mortalitas Crocidolomia binotalis setelah 24 jam pengamatan, besar kecil presentase mortalitas Crocidolomia binotalis tergantung dari besar kecilnya kadar konsentrasi zat aktif yang terkandung dalam ekstrak air bawang putih. Indikator yang menunjukkan perbedaan hasil perlakuan pada larva Crocidolomia binotalis setelah diberi ekstrak air bawang putih Allium sativum) ibandingkan dengan kelompok larva kontrol bawang putih (Allium sativum) yaitu, ada tidaknya gerakan larva setelah perlakuan tanpa ekstrak air bawang putih Allium sativum. Larva kelompok (kontrol) terlihat normal dan tidak adanya mortalitas.
Hal ini berbeda dengan larva Crocidolomia binotalis yang diberikan ekstrak air bawang putih (Allium sativum) dengan konsentrasi yang berbeda. Pada konsentrasi berbeda diperlihatkan dengan tanda gerakan Crocidolomia binotalis yang pada awalnya bergerak aktif kemudian terlihat lemas atau bergerak pasif, tubuh dari warna hijau menjadi coklat kehitaman, tubuh melingkar, dan tidak bergerak sama sekali bila disentuh. Hal ini menunjukkan bahwa ekstrak air bawang putih (Allium sativum) memberikan pengaruh terhadap perilaku larva Crocidolomia binotalis dan dapat menurunkan aktifitas dari larva Crocidolomia binotalis. Nursal et al (1997) menyatakan bahwa senyawa aktif yang terkandung dalam bawang putih adalah senyawa yang dapat menyebabkan bagian tubuh menjadi kaku, sehingga aktivitas akan terganggu dan mengakibatkan penurunan aktivitas metabolisme tubuh.

Mekanisme gangguan system saraf larva juga terjadi antara sel saraf dengan sel otot terdapat celah yang disebut sinaps. Sinaps yang berfungsi menghantarkan impuls dari sel saraf ke sel otot dengan bantuan neurotransmitter, yaitu asetilkolin. Sinaps akan berdifusi ke membran sel otot, kemudian berikatan dengan reseptor pada membran sel otot dan membentuk kompleks reseptor-neurotransmitter. Selanjutnya, neurotransmitter (asetilkolin) akan dihidrolisis oleh enzim asetilkolinterase (AchE) menjadi asetil, koenzim-A dan kolin. Hidrolisis asetilkolin membuatnya terlepas dari reseptor sehingga tidak dapat mempengaruhi membran sel otot. Hal ini yang menyebabkan kematian larva Crocidolomia binotalis (Isnaeni, 2006). Menurut Untung (1993), pestisida nabati dapat masuk ke dalam tubuh larva melalui berbagai cara antara lain, sebagai racun perut (stomach poison) yang masuk ke dalam tubuh serangga melalui alat pencernaan larva, racun kontak (contact poisoining) yang masuk melalui kulit atau dinding tubuh, dan yang terakhir fumigant atau pernafasan yang masuk ke dalam tubuh serangga melalui sistem pernafasan. Pestisida nabati dapat berfungsi untuk mengacaukan sistem hormon di dalam tubuh serangga. Banyak senyawa yang merusak sistem saraf karena berperan enzim asetilkolineterase (Asikin,2006). 
Senyawa yang juga terkadung dalam bawang putih (Allium sativum) ialah Lektin, penelitian Santosh K. at all (2012) menunjukan bahwa Lektin memberikan efek yang tepat dan reseptor sensorik dibagian mulut dan mengganggu integritas membran dan kemampuan serangga mendeteksi makanan. Selanjutnya Lektin masuk kedalam lumen usus dan berinteraksi dengan midgut protein glikolisis seperti posfat basa (APN), aminopeptidase $\mathrm{N}$ (APN), sukrasesimbionin dan lainnya. Protein ini mempunyai peran penting dalam siklus hidup serangga secara langsung maupun tidak langsung. Lektin mengganggu aktifitas protein tersebut dan menyebabkan gangguan fisiologis yang menyebabkan kematian serangga. Berdasarkan hasil pengamatan, kondisi larva setelah diberikan perlakuan terlihat dalam keadaan lemas dan pergerakannya lambat, rata-rata jumlah larva yang mati terlihat pada konsentarsi $8 \%$.

\section{KESIMPULAN DAN SARAN}

\section{Kesimpulan}

1. Ekstrak air bawang putih (Allium sativum) berpengaruh terhadap mortalitas larva Crocidolomia binotalis.

2. Pada konsentrasi $8 \%$ ekstrak air bawang putih (Allium sativum) efektif terhadap mortalitas Crocidolomia binotalis, dan berpotensi sebagai pestisida nabati.

3. Dari penentuan LC50 ekstrak air bawang putih (Allium sativum) terhadap mortalitas larva Crocidolomia binotalis menunjukan nilai LC50 sebesar 4,632\% yang berarti pada konsentrasi 4,632 \% ekstrak air bawang putih mampu mematikan larva $50 \%$ larva Crocidolomia binotalis.

\section{Saran}

Balai Proteksi Pertanian Dan Peternakan Kota Ambon dan Dinas terkait dapat menggunakan Ekstrak air bawang putih (Allium sativum) sebagai pestisida nabati yang dapat mengendalikan hama larva Crocidolomia binotalis.

\section{DAFTAR PUSTAKA}

Amiranti Sri, 2005. Kontribusi Setting Fisik RSS Dalam Pembentukan "Place Attachment" Penghuninya. Laporan Penelitian Dasar DP3M - DIKTI, FTSP, Surabaya.

Andriana C.P. 1999. Kajian daya Insektisida Ekstrak Daun Buah nona (Annona reticulate L.) Terhadap serangga Sitophilus zeamais Motsch. Skripsi Fakultas Teknologi Pertanian, Institut pertanian Bogor, Bogor.

Anonim, 2013. Balai Proteksi Pertanian dan Peternakan Kota Ambon.

Asikin, S. 2006. Bahan Tumbuhan Sebagai Pengendali Hama Ramah Lingkungan. BPTP Kalimantan Selatan.

Isnaeni, W. 2006. Fisiologi Hewan. Kanisius. Yogyakarta.

Nursal, 1997. Efektifitas cabai merah, Jurusan Hama dan Penyakit Tumbuhan Fakultas Pertanian Universitas Jember.

Prijono D, 1999. Prospek dan strategi pemamfaatan insektisida alami dalam PHT. Di dalam : Nugroho BW, Dadang, Prijono $\mathrm{D}$, penyunting. Bahan pelatihan pengembangan dan pemanfaatan insektisida alami; Bogor, 9-13 Agustus 1999. Bogor: PKPHT Institut Pertanian Bogor, HIm 1-7.

Santosh K, Upadhyay P. K Singh. CSIRBotanical Research Institute, Council of Scientific and Industrial Research, Rana Prapat Marg. Lucknow, UP 226001, India. 